\title{
Energy partitioning and substrate oxidation by Murciano-Granadina goats during mid lactation fed soy hulls and corn gluten feed blend as a replacement for corn grain
}

\author{
M. C. López and C. Fernández ${ }^{1}$ \\ Institute for Animal Science and Technology, Polytechnic University of Valencia, 46022 Valencia, Spain
}

\begin{abstract}
The aim of this experiment was to study the effect of substituting corn grain by soy hulls and corn gluten feed blend on energy partitioning, substrate oxidation, and milk performance in dairy goats during mid lactation. Ten multiparous Murciano-Granadina goats in mid lactation were fed 2 isoenergetic and isoproteic diets [19.08 $\mathrm{MJ} / \mathrm{kg}$ of dry matter (DM) and $18.7 \%$ of CP, DM basis] in a crossover design. One group of 5 goats was fed a mixed ration with $373 \mathrm{~g}$ of corn grain/ $\mathrm{kg}$ of DM (CRN diet) and the other diet replaced corn grain with $373 \mathrm{~g} /$ $\mathrm{kg}$ DM of fibrous by-products [soy hulls and gluten feed (SHGF) diet]: $227 \mathrm{~g}$ of soy hulls/kg of DM and $146 \mathrm{~g}$ of gluten feed blend $/ \mathrm{kg}$ DM. Fat was added to the SHGF diet to make it isoenergetic. After $10 \mathrm{~d}$ of adaptation, the feed intake, refusal, total fecal and urine output, and milk yield were recorded daily over a 5 -d period. Then, gas exchange measurements were recorded by a mobile open-circuit respirometry system using a head box for $10 \mathrm{~d}$. Dry matter intake was similar for both diets $(2.07 \mathrm{~kg} / \mathrm{d}$, on average). Greater and significant values were found in the SHGF diet for ammonia N, energy in urine, and oxidation of protein. Values were significantly lower for heat production of fermentation, indicating a decrease in rumen fermentation with this diet, probably due to an excess of crude protein in the diet and lack of synchronization of the nonfiber carbohydrates with rumen-degraded protein. The metabolizable energy intake was no different between CRN and SHGF treatments, with an average value of $1,444 \mathrm{~kJ} /$ $\mathrm{kg}$ of $\mathrm{BW}^{0.75}$. Due to the positive energy balance during mid lactation in this trial, most of the heat production from oxidation of nutrients derived from carbohydrate oxidation (55\%, on average), followed by oxidation of fat $(29 \%$, on average). No significant differences were observed for milk production, although milk fat was significantly greater for the SHGF diet than the CRN diet ( 7.0 vs. $5.4 \%$, respectively). Despite the different
\end{abstract}

Received December 12, 2012.

Accepted March 12, 2013

${ }^{1}$ Corresponding author: cjfernandez@dca.upv.es starch levels and fibrous content used in these mixed diets, no significant differences for the efficiency of use of metabolizable energy for late lactation were observed (0.63, on average). An average nutritive value of 7.52 MJ of net energy of lactation $/ \mathrm{kg}$ of DM was obtained. This fibrous by-product was utilized by lactating goats without detrimental effect on energy metabolism and resulted in similar performance to grain bases diet. The economic advantages and sustainability of this choice should be evaluated.

Key words: Murciano-Granadina goat, corn substitution, heat production, substrate oxidation

\section{INTRODUCTION}

To achieve maximum milk production potential by means acceptable to consumers, feeding systems for dairy ruminants need to ensure high intake of energy, among other factors. This might be accomplished by raising the dietary concentration of rapidly degraded NFC, such as starch from cereal grain. Increasing the concentration of NFC in diets for dairy cows, however, can lead to undesirable ruminal fermentation, compromising the nutrient supply for production of milk and milk components. To prevent ruminal upsets and health problems, the NRC (2001) recommended that the maximum NFC in diets for high-producing dairy cows should range from 36 to $44 \%$, depending on the total and forage NDF content of the ration. The partial replacement of cereal grain with low starch by-product feeds represents a potential alternative to overcome this limitation. By-product feeds have been used extensively in dairy cattle diets in many parts of the world as economical substitutes for corn and soybean meal. There is increasing interest in the nutritive value of byproduct feeds as nutritionists seek to manipulate NFC concentrations and undegraded intake protein of dairy ruminant diets. Soy hulls and corn gluten feed are typically used as grain replacers. According to NRC (2001), soy hulls and corn gluten feed are 2 by-product feeds that are highly digestible but low in NFC; soy hulls are high in NDF (67\%, high in cellulose) and ADF, but are low in lignin and NFC (14\%). Ludden et al. 
(1995) considered soy hulls to be a bulky concentrate similar to beet pulp, rather than roughage, in spite of the higher fiber content of soy hulls. According to NRC (2001), corn gluten feed is a good source of CP (24\%), much of which is ruminally degraded. Corn gluten feed $(36 \% \mathrm{NDF})$ is high in hemicellulose and moderate in NFC (30\%). Therefore, these by-products are widely available and an affordable source to supply energy for production.

The Spanish ruminant production system (Interal, 2008; FEDNA, 2009) is based on high use of concentrate (40 to 70\%), with mixed diets instead of whole-forage rations. Consuming high levels of concentrate in the diet is common practice in Spain due to the lack of pasture; nutritionists are aware of the importance of ruminants in converting fibrous feeds, unsuitable for direct human consumption, into high-quality protein sources such as milk and meat. Goat livestock in Spain occupies the second position after France in the European Union, with $30 \%$ of the milk production (MAAMA, 2012). The aim of this experiment was to study the effect of substitution of corn grain by soy hulls and corn gluten feed blend on energy partitioning, substrate oxidation, and milk performance in dairy goats during mid lactation.

\section{MATERIALS AND METHODS}

The experimental procedure was approved by the Animal Use and Care Committee of the Polytechnic University of Valencia (Spain) and followed the codes of practice for animals used in experimental works proposed by the European Union (European Council, 2003).

\section{Animals and Feeding}

The experiment was conducted in a crossover design with 10 lactating dairy goats kept in 2 groups and fed 1 of 2 diets in two 25-d periods. The 10 multiparous mature Murciano-Granadina goats in mid lactation had similar BW (43.07 $\pm 2.5 \mathrm{~kg}$ of BW). Goats were fed 2 different mixed diets; one group was fed a mixed diet with $373 \mathrm{~g}$ of corn grain/ $\mathrm{kg}$ of DM (CRN diet) and the other on diet substituted corn with $373 \mathrm{~g}$ of byproducts/kg DM [soy hulls and gluten feed (SHGF) diet] in the following proportion: 227 soy hulls and 146 gluten feed, both expressed in $\mathrm{g} / \mathrm{kg}$ of DM. Five goats per group were used to determine apparent total-tract digestibility, gas exchange, oxidation of nutrients, and milk yield. Ruminal fermentation parameters were determined in the first period of the experiment. Alfalfa hay was cut into 2.5 -cm pieces (Skiold Sæby A/S, Kjeldgaardsvej, Denmark) and the concentrate was mixed and pelleted along with the premix (Table 1).
Mixed diets were isoenergetic, with an average value of $19.08 \mathrm{MJ} / \mathrm{kg}$ of DM for gross energy (GE), and isoproteic $18.7 \%$ of CP (DM basis). Fat was included in the SHGF diet to make it isoenergetic (2.3\% lard and $1.3 \%$ bypass fat). Besides, the SHGF diet had 2.3\% molasses compared with $0.1 \%$ in the CRN diet. Starch levels were 27.99 and $6.57 \%$ of DM for the CRN and SHGF diets, respectively. Nutrient requirements followed the recommendation of Lachica and Aguilera (2003) and Fundación Española para el Desarrollo de la Nutrición Animal (FEDNA, 2009) for goats in lactation. Intake was ad libitum, with diets offered at $110 \%$ of consumption on the preceding few days. Half of the daily ration was offered at $0800 \mathrm{~h}$ and half at $1600 \mathrm{~h}$, respectively. Goats had free access to water.

\section{Experimental Schedule and Measurements}

Goats were fed with experimental diets in pens for $10 \mathrm{~d}$ and then allocated to individual metabolism cages in thermoneutral conditions $\left(20\right.$ to $23^{\circ} \mathrm{C}$ determined by

Table 1. Ingredients ( $\mathrm{g} / \mathrm{kg}$ of $\mathrm{DM})$ and chemical composition of the diets (\% of DM): corn grain (CRN) and soy hulls and corn gluten feed blend (SHGF)

\begin{tabular}{|c|c|c|}
\hline \multirow[b]{2}{*}{ Item } & \multicolumn{2}{|c|}{ Diet } \\
\hline & $\mathrm{CRN}$ & SHGF \\
\hline \multicolumn{3}{|l|}{ Ingredient, $\mathrm{g} / \mathrm{kg}$ of $\mathrm{DM}$} \\
\hline Alfalfa hay & 445.9 & 445.2 \\
\hline Corn & 372.8 & - \\
\hline Soybean meal $(44 \% \mathrm{CP})$ & 165.7 & 113.4 \\
\hline Soy hulls & - & 226.8 \\
\hline Gluten feed $(18 \% \mathrm{CP})$ & - & 145.7 \\
\hline Lard $^{1}$ & - & 22.7 \\
\hline Bypass fat ${ }^{2}$ & - & 13.0 \\
\hline Molasses & 1.2 & 23.3 \\
\hline Calcium carbonate & 9.7 & 4.7 \\
\hline Premix $^{3}$ & 2.6 & 2.6 \\
\hline Sodium chloride & 2.1 & 2.6 \\
\hline \multicolumn{3}{|c|}{ Chemical composition, $\%$ of DM } \\
\hline DM, $\%$ & 87.60 & 88.20 \\
\hline $\mathrm{OM}$ & 92.51 & 91.27 \\
\hline $\mathrm{CP}$ & 18.60 & 18.80 \\
\hline Ether extract & 2.13 & 5.04 \\
\hline $\mathrm{NDF}$ & 34.82 & 47.45 \\
\hline $\mathrm{ADF}$ & 19.06 & 27.79 \\
\hline $\mathrm{NFC}^{4}$ & 36.96 & 19.98 \\
\hline Starch & 27.99 & 6.57 \\
\hline Gross energy, MJ/kg of DM & 18.76 & 19.40 \\
\hline
\end{tabular}

${ }^{1}$ Fused lard provided by Valgess S.L. (Carpesa, Valencia, Spain).

${ }^{2}$ Bypass fat of palm FA distillate. Provided by Norel Animal Nutrition (Norel S.A., Madrid, Spain).

${ }^{3}$ Provided by Nacoop S.A. (Madrid, Spain). Premix composition: 40 $\mathrm{mg}$ of $\mathrm{Se} / \mathrm{kg}, 250 \mathrm{mg}$ of $\mathrm{I} / \mathrm{kg}, 80 \mathrm{mg}$ of $\mathrm{Co} / \mathrm{kg}, 3,000 \mathrm{mg}$ of $\mathrm{Cu} /$ $\mathrm{kg}, 6,000 \mathrm{mg}$ of $\mathrm{Fe} / \mathrm{kg}, 23,400 \mathrm{mg}$ of $\mathrm{Zn} / \mathrm{kg}, 29,000 \mathrm{mg}$ of $\mathrm{Mn} / \mathrm{kg}$, $60,000 \mathrm{mg}$ of $\mathrm{S} / \mathrm{kg}, 60,000 \mathrm{mg}$ of $\mathrm{Mg} / \mathrm{kg}, 2,000,000 \mathrm{IU}$ of vitamin A/ $\mathrm{kg}, 400,000 \mathrm{IU}$ of vitamin $\mathrm{D}_{3} / \mathrm{kg}, 2,000 \mathrm{mg}$ of vitamin $\mathrm{E} / \mathrm{kg}, 10,000 \mathrm{mg}$ of nicotinic acid $/ \mathrm{kg}$, and $20,300 \mathrm{mg}$ of choline $/ \mathrm{kg}$.

${ }^{4} \mathrm{NFC}=100-(\mathrm{NDF}+\mathrm{ash}+\mathrm{CP}+$ ether extract $)$. 
a Hobo probe; Onset data loggers; Onset Computer Corp., Cape Cod, MA). After $10 \mathrm{~d}$ of adaptation, totaltract apparent digestibility, energy balance, and ruminal fermentation parameters were determined; the feed intake, refusal, and total fecal, urine, and milk output were recorded daily for each goat during a 5-d period, as well as the BW at the beginning and end of the period. Feces were collected in wire-screen baskets placed under the floor of the metabolism crates and urine was collected through a funnel into plastic buckets containing $100 \mathrm{~mL}$ of $10 \%$ (vol/vol) $\mathrm{H}_{2} \mathrm{SO}_{4}$ to acidify the urine of each goat. Representative samples (20\%) of the diet, feces, and urine were collected over 5 consecutive days and stored at $-20^{\circ} \mathrm{C}$, and then pooled for chemical analysis. The goats were milked once daily at $0700 \mathrm{~h}$ with a portable milking machine (Flaco, model DL-170; J. Delgado S.A., Ciudad Real, Spain). Immediately after milking, the individual milk yield was weighed and, after mixing, daily samples were put in a bottle with $20 \mathrm{mg}$ of potassium dichromate as a preservative and stored at $4^{\circ} \mathrm{C}$ before analyses. Ruminal fluid samples were collected by stomach tube before the morning feeding on the last day of the apparent digestibility trial. Ruminal fluid $\mathrm{pH}$ was immediately determined using a model 265A portable $\mathrm{pH}$ meter (Orion Research Inc., Beverly, MA). A 5-mL subsample of strained ruminal fluid was acidified to $\mathrm{pH} 2.0$ and mixed with $50 \% \mathrm{H}_{2} \mathrm{SO}_{4}$ and frozen until analysis for short-chain FA (SCFA).

Then, gas exchange was measured for each goat for $24 \mathrm{~h}$ (5 goats/treatment) using a head box designed for small ruminants. Therefore, $10 \mathrm{~d}$ were taken for each period in the crossover design. The respirometry system had 2 separate sampling lines. The main line sucked air through a head box equipped with an air filter to keep dust out. Head hood dimensions were 36 -cm deep $\times 53$ $\mathrm{cm}$ wide $\times 116$-cm high, giving a total internal volume of $219 \mathrm{~L}$. The hood was fitted with a polycarbonate window and drawer at the front to facilitate feeding and watering. A tightly woven nylon curtain with a hole for the animal neck, which was attached to the rear panel of the hood, was tied around the animal's neck with a nylon drawstring to minimize gas leakage. Fresh outdoor air was introduced into the hood via a hose connected to a box entrance. The gas outlet was across a pipe attached on top of the hood equipped with an air filter to prevent dust in the circuit. Through this pipe the gas flowed from the ventilated head hood to the open-circuit respiratory system, which monitored gaseous exchanges by each animal.

The head box was attached to a 2.5 -cm (i.d.) corrugated polyvinyl chloride (PVC) tube connected to the flow meter. Total air flow through the system was measured by a mass flow meter with a range from 0 to 10,000
L/h (thermal mass flow meter Sensyflow VTS; ABB Automation Products GmbH, Alzenau, Germany) and regulated by a manual valve at $3,000 \mathrm{~L} / \mathrm{h}$. Air suction was by a centrifugal fan (CST60; Soler \& Palau Inc., Parets del Vallès, Barcelona, Spain) with $310 \mathrm{~m}^{3} / \mathrm{h}$ as the maximum capacity located at the end of the main sampling line, with free escape for the air. Total flow was recorded (Totalizer VT-S; ABB Automation Products $\mathrm{GmbH}$ ) and screen (C150 Universal Process Indicator; ABB Automation Products $\mathrm{GmbH}$ ) displayed. In addition, the mass flow meter had a digital output and was connected to a computer. A subsampling line (polyethylene tubing, 5-mm i.d.) was located after the mass flow meter to take a sample of gas from the main line using a membrane pump (ABB Automation Products $\mathrm{GmbH}$ ) of $250 \mathrm{~L} / \mathrm{h}$ capacity. It was attached to a rotameter (DK800; ABB Automation Products GmbH) with a valve to set the desired flow rate into the gas analyzer (Easyflow 3020 model; ABB Automation Products $\mathrm{GmbH}$ ). The $\mathrm{CH}_{4}$ and $\mathrm{CO}_{2}$ were measured by using the infrared principle with a concentration range from 0 to 0.15 and 0 to $1.5 \%$, respectively; $\mathrm{O}_{2}$ was measured by using the paramagnetic principle from 19 to $21 \%$ and equipped with an atmospheric compensation module to offset changes in pressure. Although the unit was an autocalibrated model, before each test, analyzers were calibrated with reference gases. This analyzer was controlled by Modbus communication protocol with a personal computer (Fujitsu Siemens Lifebook Series, Pentium 4 laptop; Fujitsu Siemens Computers GmbH, Munich, Germany) under a LabVIEW software (http://www.ni.com/labview) environment to save the data to the hard disk each minute. Fernández et al. (2012a) describes the mobile open-circuit respirometry system used for these measurements.

The whole system was calibrated by injecting pure $\mathrm{N}_{2}$ into the head box (McLean and Tobin, 1987), determined gravimetrically using a precision scale. Calibration factors were calculated according to Brockway et al. (1971). The $\mathrm{CH}_{4}$ and $\mathrm{CO}_{2}$ production and $\mathrm{O}_{2}$ consumption were calculated as described by Aguilera and Prieto (1986). An initial atmospheric air sample was collected and the gas concentrations were used as reference for calculations.

\section{Chemical Analysis}

Feed, feed refusal, and feces samples were first dried in a forced-air oven at $55^{\circ} \mathrm{C}$ for $48 \mathrm{~h}$ and then ground to pass a 1-mm screen. Urine was dried by lyophilization. Chemical analyses of the diet, refusals, and feces were conducted for DM, ash, ether extract (EE), and CP according to AOAC International (2000) methods. The DM content of diets and feces was determined by 
oven drying at $102 \pm 2^{\circ} \mathrm{C}$ for $24 \mathrm{~h}$ and $\mathrm{OM}$ content was determined by incineration in an electric muffle furnace at $550^{\circ} \mathrm{C}$ for $6 \mathrm{~h}$. Ether extract was extracted with petroleum ether after acid hydrolysis to recover saponified fat (Soxtec System HT; Tecator, Hillerød, Denmark; 1047 hydrolyzing unit and 1043 extraction unit). The ADF and NDF were measured in an Ankom fiber analyzer (A220; Ankom Technology Corp., Fairport, NY) according to Van Soest et al. (1991), using sodium sulfite and $\alpha$-amylase. The NFC content of diets was calculated by the difference method based on chemical analysis of individual feeds according to NRC (2001): NFC $=100-\mathrm{NDF}-$ ash $-\mathrm{CP}-\mathrm{EE}$. The GE content of the dried samples (feed, feces, urine, and milk) was analyzed in an adiabatic bomb calorimeter (Gallenkamp Autobomb; Weiss Gallenkamp Ltd., Loughborough, UK). Milk composition (fat, protein, lactose, and total milk solids content) was analyzed with infrared analyzer (MilkoScan FT120; Foss Electric A/S, Hillerød, Denmark). Starch content was determined by the enzymatic method ( $\alpha$-amylase obtained from Sigma-Aldrich Chemie GmbH, Steinheim, Germany) according to Batey (1982).

Determination of SCFA was based on the method previously described by Jouany (1982). Samples were filtered through $0.45-\mu \mathrm{m}$ cellulose syringe filters. One hundred microliters of an internal standard solution ( $0.4 \mathrm{~g}$ of 4-metil-valeric acid diluted in $100 \mathrm{~mL}$ of deionized water) and $0.1 \mathrm{~mL}$ of a preservative (a mix of $5 \%$ $\mathrm{H}_{3} \mathrm{PO}_{4}$ and $1 \% \mathrm{ClHg}$ in deionized water) were added to $0.8 \mathrm{~mL}$ of filtrate. One microliter from each sample was injected into a gas chromatograph (Fisons 8000 series; Fisons Instruments SpA, Milan, Italy) equipped with a split/splitless injector and flame ionization detector. Short-chain FA separation was performed in a DBFFAP capillary column $(30 \mathrm{~m} \times 0.25 \mathrm{~mm} \times 0.25-\mu \mathrm{m}$ film thickness) J\&W Scientific Inc. (Folsom, CA). The carrier gas was $\mathrm{N}_{2}$ at a constant pressure of $120 \mathrm{kPa}$. Both detector and injector temperatures were set at $245^{\circ} \mathrm{C}$. The initial oven temperature was set at $115^{\circ} \mathrm{C}$, held for $5 \mathrm{~min}$, and increased to $230^{\circ} \mathrm{C}$ at $8.5^{\circ} \mathrm{C} / \mathrm{min}$, and finally maintained at that temperature for $10 \mathrm{~min}$. Short-chain FA were identified by comparing their retention times with a standard (46975-U; Supelco Inc., Bellefonte, PA).

\section{Calculations}

Metabolizable energy intake (MEI) was calculated as the difference between GE intake and energy losses in feces, urine, and $\mathrm{CH}_{4}$ (with an energy equivalent value of $39.5 \mathrm{~kJ} / \mathrm{L} \mathrm{CH}_{4}$; Brouwer, 1965). Heat production (HP) was calculated according to Brouwer (1965) for $\mathrm{O}_{2}$ consumption, $\mathrm{CO}_{2}$, and $\mathrm{CH}_{4}$ production, and urine-N (Nur) as follows:

$$
\begin{gathered}
\mathrm{HP}(\mathrm{kJ})=16.18 \times \mathrm{O}_{2}+5.02 \times \mathrm{CO}_{2} \\
-2.17 \times \mathrm{CH}_{4}-5.99 \times \text { Nur }
\end{gathered}
$$

where gases are expressed in liters per day and Nur is urine- $\mathrm{N}$ in grams per day. The nonprotein respiratory quotient (RQnp) was determined as RQnp $=\left[\mathrm{CO}_{2}-\right.$ $(\mathrm{Nur} \times 6.25 \times 0.774)] /\left[\mathrm{O}_{2}-(\mathrm{Nur} \times 6.25 \times 0.957)\right]$. Recovered energy was calculated as the difference between MEI and HP. Body tissue energy ( $\mathbf{T E}_{\text {body }}$ ) was the difference between recovered energy and milk energy $\left(\mathbf{E}_{\text {milk }}\right)$.

Energy associated with the oxidation of protein (OXP), carbohydrate (OXCHO), and fat (OXF) was calculated by the method of Brouwer (1958) and Chwalibog et al. (1997) for ruminants. The production of SCFA from carbohydrate fermentation is followed by $\mathrm{CO}_{2}$ and $\mathrm{CH}_{4}$ production. Fahey and Berger (1988) demonstrated a $\mathrm{CO}_{2}: \mathrm{CH}_{4}$ ratio of $3: 1$ and 1.7:1 for highgrain and high-forage diets, respectively. To estimate the $\mathrm{CO}_{2}: \mathrm{CH}_{4}$ ratio of our diets, SCFA was determined and as diets contained $45 \%$ alfalfa hay, a value of this ratio was obtained. The $\mathrm{CO}_{2}$ production from oxidation $\left(\mathbf{C O}_{2} \mathbf{x}\right)$ was calculated as $\mathrm{CO}_{2}-\left(\mathrm{CO}_{2} / \mathrm{CH}_{4} \times \mathrm{CH}_{4}\right)$. The calculations were carried out as follows:

$$
\begin{gathered}
\text { OXP }=6.25 \times \text { Nur } \times 18.42(\mathrm{~kJ} / \mathrm{g}), \\
\text { OXCHO }=\left(-2.968 \times \mathrm{O}_{2}+4.174 \times \mathrm{CO}_{2} \mathrm{x}\right. \\
-2.446 \times \mathrm{Nur}) \times 17.58(\mathrm{~kJ} / \mathrm{g}), \\
\mathrm{OXF}=\left(1.719 \times \mathrm{O}_{2}-1.719 \times \mathrm{CO}_{2} \mathrm{x}\right. \\
-1.963 \times \mathrm{Nur}) \times 39.76(\mathrm{~kJ} / \mathrm{g}) .
\end{gathered}
$$

Then, the HP from oxidation $(\mathbf{H P x})$ was calculated as follows:

$$
\begin{gathered}
\operatorname{HPx}(\mathrm{kJ})=16.18 \times \mathrm{O}_{2}+5.02 \\
\times \mathrm{CO}_{2} \mathrm{x}-5.99 \times \text { Nur. }
\end{gathered}
$$

Gases were expressed in liters per day and Nur in grams per day. Heat of fermentation was estimated by subtracting HP from HPx.

The efficiency of use of ME for lactation in absence of change in body energy stores was calculated according to the Agricultural Research Council (ARC, 1980). Energy lost from the body, indicating mobilization of 
body fat reserves in support of milk secretion, was assumed to be used for milk synthesis, with an efficiency of 0.84 and the concomitant energy storage during lactation was taken to be 0.95 times the milk secretion efficiency. Consequently, the corrected milk energy was estimated as $\mathrm{E}_{\text {milk }}+(0.84 \times$ negative energy retention $)$ $+(1.05 \times$ positive energy retention). The efficiency of use of ME for milk production ( $\left.\mathbf{k}_{1-\mathrm{ARC}}\right)$ was calculated as corrected milk energy/( $\left.\mathrm{ME}-\mathbf{M E}_{\mathrm{M}}\right)$, with $\mathrm{ME}_{\mathrm{M}}$ being the ME for maintenance, which was obtained from the estimation of Aguilera et al. (1990) for Granadina goats from both positive and negative energy retentions $\left(401 \mathrm{~kJ} / \mathrm{kg}\right.$ of $\left.\mathrm{BW}^{0.75}\right)$.

As ME could be used for milk synthesis and energy storage in the body, an attempt to estimate the efficiency of ME for milk and body retention is proposed. Recovery energy was partitioned into 2 portions; one used for milk production $\left(\mathrm{E}_{\text {milk }}\right)$ and the other for body tissue energy gain $\left(\mathrm{TE}_{\text {body }}\right)$. The basic relationship was expressed quantitatively in the following set of equations:

$$
\begin{gathered}
\mathrm{k}_{\mathrm{l}}=\mathrm{E}_{\text {milk }} /(\text { Prop } \times \mathrm{MEA}), \\
\mathrm{k}_{\mathrm{g}}=\mathrm{TE}_{\text {body }} /(1-\text { Prop }) \times \mathrm{MEA},
\end{gathered}
$$

where $\mathbf{k}_{1}$ is the efficiency of use of ME for milk production and $\mathbf{k}_{\mathbf{g}}$ is the efficiency of ME for tissue gain. The proportion Prop represents the fraction of the ME available for productive purposes (MEA) that is used for milk synthesis and (1 - Prop) is the fraction of MEA used for body tissue energy gain; MEA was calculated by subtracting maintenance requirements from MEI, where maintenance was obtained from estimations (401 $\mathrm{kJ} / \mathrm{kg}$ of $\mathrm{BW}^{0.75}$ ) by Aguilera et al. (1990). The next Michaelis-Menten equation was assumed to express the effect of MEA on the partition coefficient:

$$
\text { Prop }=\text { Prop }_{\max } \times \mathrm{MEA} /(\mathrm{Z}+\mathrm{MEA}),
$$

where Prop $_{\max }$ is the maximum fraction of MEA that can be used for milk production and $\mathrm{Z}$ represents the level of MEA at which $50 \%$ of maximum fraction of MEA is used for milk production.

\section{Statistical Analyses}

The effects of corn substitution with by-products on intake, digestibility, ruminal fermentation parameters, milk yield, energy balance, and oxidation of nutrients were analyzed using the mixed model (PROC MIXED) from SAS software (SAS Institute, 2001). The experiment was conducted as a crossover design: each goat received both treatments in 2 periods. Goat served as the experimental unit for all data. The model for the dependent variables included the fixed effect of diet and period with goat as random effect. The following statistical model was used: $\mathrm{Y}=\mu+\mathrm{D}+\mathrm{T}+$ goat + $\varepsilon$, where $\mathrm{Y}$ is the dependent variable, $\mu$ is the overall mean; D and $\mathrm{T}$ are the fixed effects of diet and period of time, respectively; goat is the random effect of goat; and $\varepsilon$ is the random error. Least squares means are reported throughout and differences were considered significant at $P<0.05$.

\section{RESULTS AND DISCUSSION}

No significant effect was observed for the period of time in the crossover design.

\section{Feed Intake, Digestibility, and Rumen Fermentation}

Spanish production systems are based on high use of concentrate and less pasture. Our study shows a representative diet ( $55 \%$ concentrate) for high-production dairy goats. Alternative feedstuffs (soy hulls, gluten feed, citrus pulp, and beet pulp) are viable replacements for traditional feedstuffs (corn and barley) for lactating ruminants when they are priced economically and available, or when traditional feedstuff prices are high. Corn is mainly imported from other countries and so is very costly today in Spain. In this trial, considering the importance of ruminants in converting fibrous feeds into protein, corn was partially substituted with fibrous by-products. The CRN diet had an NFC level of $37 \%$ and $\mathrm{NDF}$ of $35 \%$, values almost within the range recommended by NRC (2001) for dairy cows (NFC maximum is between 36 and $44 \%$, NDF minimum is between 25 and 33\%). However, the SHGF diet had a NFC value of $20 \%$ and NDF of $47 \%$ due to the substitution of corn, mainly with fibrous by-products.

The partial replacement of corn grain with low-starch by-product feeds, such as soy hulls, represents a potential alternative to overcome this limitation. In this study, the NFC content was 37 and $20 \%$ of DM in CRN and SHGF, respectively (Table 1).

Intake and total-tract apparent digestibility of nutrients by Murciano-Granadina dairy goats are shown in Table 2. The DMI was similar for both diets (2.07 $\mathrm{kg} / \mathrm{d}$, on average). Apparent total-tract digestibility was significant $(P<0.05)$ in DM, OM, EE, NDF, and starch. The numerically higher level of starch and lower level of fiber in the CRN diet compared with the SHGF diet appeared to be the main factor responsible for the decrease in DM and OM apparent digestibility in the SHGF diet; that is to say, significant reduction in $\mathrm{DM}$ and $\mathrm{OM}$ digestibility with increasing NDF content (from 35 to $48 \%$ of NDF on DM basis for CRN and 
Table 2. Body weight $(\mathrm{kg})$, intake $(\mathrm{kg} / \mathrm{d})$, and apparent digestibility coefficients (\%) of Murciano-Granadina goats $(\mathrm{n}=20)$ during mid lactation according to the type of diet

\begin{tabular}{lrrrl}
\hline & \multicolumn{2}{c}{ Diet $^{1}$} & & \\
\cline { 2 - 3 } Item & CRN & SHGF & SEM & $\begin{array}{c}\text { P-value } \\
\text { (diet) }\end{array}$ \\
\hline BW, kg & 43.08 & 43.05 & 0.194 & 0.95 \\
DMI, kg/d & 2.04 & 2.10 & 0.027 & 0.067 \\
DM, \% & 67.62 & 63.84 & 0.830 & 0.041 \\
OM, \% of DM & 69.24 & 65.05 & 0.864 & 0.029 \\
CP, \% of DM & 69.24 & 70.61 & 0.753 & 0.44 \\
EE, \% of DM & 66.35 & 83.92 & 2.370 & 0.0009 \\
NDF, \% of DM & 36.61 & 49.53 & 1.893 & 0.0005 \\
Starch, \% of DM & 99.09 & 99.62 & 0.090 & 0.57 \\
GE, ${ }^{3} \%$ & 68.75 & 66.19 & 0.911 & 0.26 \\
\hline
\end{tabular}

${ }^{1} \mathrm{CRN}=$ corn diet; SHGF $=$ soy hulls and gluten feed diet.

${ }^{2} \mathrm{EE}=$ ether extract.

${ }^{3} \mathrm{GE}=$ gross energy.

SHGF, respectively) and ADF content (from 19 to $28 \%$ $\mathrm{ADF}$ on DM basis for CRN and SHGF, respectively) combined with the greater value of starch for the CRN diet than the SHGF diet (30 vs. $7 \%$ of starch, DM basis). Similar tendencies were observed in lactating dairy goats when the level of ADF increased from 14 to $26 \%$ (Santini et al., 1992).

Fats are commonly added to diets for dairy animals to increase energy density and improve handling characteristics. Greater $(P<0.05)$ digestibility of EE was found for the SHGF diet than the CRN diet. Although the levels were 2 and $5 \% \mathrm{EE}$ for the CRN and SHGF diets, respectively, the level of fat in the CRN diet came from raw source ingredients, and fat was probably linked to carbohydrates and, therefore, less available for digestion compared with the source of external added fat for the SHGF diet: lard and bypass fat.

Neutral detergent fiber digestibility was significantly greater for the fibrous diet (50 vs. $37 \%$ for the SHGF and CRN diets, respectively), probably due to the source of fibrous ingredients (soy hulls, gluten feed, and alfalfa hay) with different physical and chemical properties, compared with the CRN diet, where the main supply of fiber came from alfalfa hay. The fiber of byproducts has different physical and chemical properties from forage NDF; in particular, its particles have small dimensions and a high density (Firkins, 1997), although soy hull density is light. Starch digestibility was almost complete for the 2 diets, although the SHGF diet had a lower amount of starch (7 vs. $28 \%$ starch, DM basis, respectively). Different authors reported higher starch apparent digestibility; barley starch is roughly $94 \%$ fermented in the rumen, whereas corn starch is around $78 \%$ fermented in the rumen of cows and greater for sheep (Waldo, 1973). A review by Huntington (1997) of ruminant starch utilization reported ruminal digest- ibility of whole corn to be $60 \%$ and total-tract digestibility as $92 \%$. Therefore, this latter value is affected by the corn source, ruminant species, processing method, and percentage of corn in the diet. The CRN diet with higher starch digestibility is accompanied by lower fiber digestibility.

Rumen fermentation parameters obtained are shown in Table 3. No effect of period of time is shown because rumen liquid extraction was done only in the first part of the trial. The average rumen $\mathrm{pH}$ never fell below 6.2, so the values obtained can be considered sufficiently high to maintain normal rumen fermentation. The highest fibrous ingredients in SHGF diet were the cause of the greater $\mathrm{pH}(P<0.05)$ than in $\mathrm{CRN}$ diet. Goats fed fibrous by-products had greater ammonia N production $(P<0.05)$ than those fed the CRN diet $(49.58$ vs. $31.77 \mathrm{mg} / \mathrm{dL}$, respectively), probably linked to the lower $\mathrm{N}$ expenditure by ruminal bacteria to synthesize microbial protein (Casper et al., 1999). These greater values obtained are likely due to the average value of $\mathrm{CP}$ in diets (18.7\% CP, DM basis) and because of $\mathrm{N}$ recycling, which appears more extensive in goats than cattle and sheep (NRC, 2007). Bava et al. (2001) with Saanen dairy goats at mid lactation found ammonia N values of 28.8 and $53.3 \mathrm{mg} / \mathrm{dL}$ for diets with 14.8 and $21.4 \% \mathrm{CP}$ (on a DM basis), respectively. The ratios of acetic to propionic acids were greater than 3.0 for both diets, possibly because the end products of fiber fermentation, due to cellulolytic organism activity, include a high proportion of acetic acid (both diets had $45 \%$ alfalfa hay). A significant increase of acetic acid in the rumen when goats fed the more fibrous diet was observed (60.3 and $64.2 \mathrm{~mol} / 100 \mathrm{~mol}$ for the CRN and SHGF diets, respectively). The rest of the SCFA showed no significant differences between diets. Therefore, the SHGF diet had low starch content and the energy it provides would be mainly in the form of highly digestible fiber, as Drewnoski et al. (2011) found in growing steers when supplementing hay with soy hulls and corn gluten feed.

\section{Energy Balance}

The average value obtained for the calibration factor by releasing a known volume of $\mathrm{N}_{2}$ into the respirometry system was $1.003 \pm 0.01307$. The daily energy balance is displayed in Table 4. Statistically significant differences $(P<0.05)$ were observed for GE intake. Energy losses in feces were significant $(P<0.05)$ and greater for the SHGF than the CRN diet, probably due to the higher level of fat in the diet. Ludden et al. (1995) reported that the dietary addition of fat at more than $3 \%$ of DM may decrease digestibility of fibrous feedstuffs such as soy hulls by inhibiting fibrolytic bacteria. In our trial, 
Table 3. $\mathrm{pH}$, ammonia- $\mathrm{N}\left(\mathrm{NH}_{3}-\mathrm{N}, \mathrm{mg} / \mathrm{dL}\right)$, and short-chain FA (SCFA; mol/100 mol) of Murciano-Granadina goats $(\mathrm{n}=20)$ during mid lactation according to the type of diet

\begin{tabular}{|c|c|c|c|c|}
\hline \multirow[b]{2}{*}{ Item } & \multicolumn{2}{|c|}{ Diet $^{1}$} & \multirow[b]{2}{*}{ SEM } & \multirow[b]{2}{*}{$P$-value } \\
\hline & CRN & SHGF & & \\
\hline $\mathrm{pH}$ & 6.86 & 6.90 & 0.011 & 0.048 \\
\hline $\mathrm{NH}_{3}-\mathrm{N}$ & 31.77 & 49.58 & 4.458 & 0.048 \\
\hline Acetic acid & 60.26 & 64.22 & 0.786 & 0.0071 \\
\hline Propionic acid & 19.98 & 17.15 & 1.030 & 0.18 \\
\hline Isobutyric acid & 2.04 & 1.93 & 0.166 & 0.76 \\
\hline Butyric acid & 11.93 & 11.61 & 0.254 & 0.54 \\
\hline Isovaleric acid & 3.51 & 3.01 & 0.255 & 0.34 \\
\hline$n$-Valeric acid & 1.97 & 1.79 & 0.056 & 0.095 \\
\hline$n$-Caproic acid & 0.30 & 0.30 & 0.025 & 0.99 \\
\hline
\end{tabular}

${ }^{1} \mathrm{CRN}=$ corn diet; SHGF $=$ soy hulls and gluten feed diet.

we observed no decrease in fiber digestibility, probably due to the excretion of fat in feces. Dietary differences in urine energy losses of the SHGF diet were significant $(P<0.05)$ and higher than in the $\mathrm{CRN} \operatorname{diet}(46.9$ vs. $23.4 \mathrm{~kJ} / \mathrm{kg}$ of $\mathrm{BW}^{0.75}$, respectively) due to lack of efficiency for protein use (greater values of ammonia $\mathrm{N}$ on ruminal liquor; Table 3) and probably high level of CP in the diets; $18.7 \%$ on a DM basis, on average). Ruminal ammonia $\mathrm{N}$ not used for microbial protein synthesis is likely to be excreted in urine (Hoover and Stokes, 1991). Islam et al. (2000) found similar results where the fibrous diet was also higher in energy losses in urine $\left(43.7 \mathrm{~kJ} / \mathrm{kg}\right.$ of $\left.\mathrm{BW}^{0.75}\right)$ than the less-fibrous diet $(29.1$ $\mathrm{kJ} / \mathrm{kg}$ of $\mathrm{BW}^{0.75}$ ). Bava et al. (2001) found values of 62 and $99 \mathrm{~kJ} / \mathrm{kg}$ of $\mathrm{BW}^{0.75}$ for diets with 14.8 and $21.4 \%$ $\mathrm{CP}$ (on a DM basis), respectively. The greater digestibility of DM and OM, lower ammonia N, and greater heat of fermentation would seem to indicate that more fermentative activity was taking place with the CRN diet. The HP of fermentation was significantly different $(P<0.05)$, showing greater fermentation activity in the CRN than the SHGF diet (16.03 vs. $14.30 \mathrm{~kJ} /$ $\mathrm{kg}$ of $\mathrm{BW}^{0.75}$, respectively). Therefore, energy losses in $\mathrm{CH}_{4}$ were greater for the $\mathrm{CRN}$ diet $(101.38 \mathrm{~kJ} / \mathrm{kg}$ of $\left.\mathrm{BW}^{0.75}\right)$ than the SHGF diet $\left(96.44 \mathrm{~kJ} / \mathrm{kg}\right.$ of $\left.\mathrm{BW}^{0.75}\right)$, although not significant $(P=0.069)$. Methane energy values obtained by other authors for lactating goats were within the range obtained in this experiment, so Aguilera et al. (1990) found values from 83 to $117 \mathrm{~kJ} /$ $\mathrm{kg}$ of $\mathrm{BW}^{0.75}$, both with diets based on pelleted alfalfa hay and barley. Bava et al. (2001) did not observe significant differences, but the value of energy losses as $\mathrm{CH}_{4}$ was 131 and $115 \mathrm{~kJ} / \mathrm{kg}$ of $\mathrm{BW}^{0.75}$ for Saanen goats at mid lactation fed a silage-based forage diet and a nonforage diet, respectively. In that study, the ammonia $\mathrm{N}$ followed an opposite trend to that in our trial: 22.8 versus $53.3 \mathrm{mg} / \mathrm{dL}$ for forage and nonforage diets, respectively. It is generally accepted that utilization of ammonia $\mathrm{N}$ for rumen microbial protein synthesis increases when diets contain a greater amount of NSC. The major factor limiting utilization of $\mathrm{N}$ was a readily available energy source. In our study, the CRN diet may have been fermented more readily in the rumen than the SHGF diet. Also at mid lactation, Tovar-Luna et al. (2010) with Alpine goats reported an average value of $85 \mathrm{~kJ}$ of $\mathrm{CH}_{4} / \mathrm{kg}$ of $\mathrm{BW}^{0.75}$ when does consumed a $60 \%$ concentrate diet (31\% NDF), and 63 $\mathrm{kJ} / \mathrm{kg}$ of $\mathrm{BW}^{0.75}$ for does consuming $20 \%$ concentrate (43\% of NDF), although those authors did not show any ruminal parameter or provide information about the starch level. In our study, it seems that greater dietary concentration of starch increased the utilization of ruminal ammonia $\mathrm{N}$ for synthesis of microbial protein, as reported by Hoover and Stokes (1991).

The MEI was no different between the CRN and SHGF treatments, with an average value of $1,444 \mathrm{~kJ} /$ $\mathrm{kg}$ of $\mathrm{BW}^{0.75}$. The HP was not significant between diets, with an average value of $794 \mathrm{~kJ} / \mathrm{kg}$ of $\mathrm{BW}^{0.75}$, although a tendency to higher values in the $\mathrm{CRN}$ diet was ob-

Table 4. Daily energy balance $\left(\mathrm{kJ} / \mathrm{kg}\right.$ of $\left.\mathrm{BW}^{0.75}\right)$ of MurcianoGranadina goats $(\mathrm{n}=20)$ during mid lactation according to the type of diet

\begin{tabular}{|c|c|c|c|c|}
\hline \multirow[b]{2}{*}{ Item $^{1}$} & \multicolumn{2}{|c|}{ Diet $^{2}$} & \multirow[b]{2}{*}{ SEM } & \multirow{2}{*}{$\begin{array}{c}P \text {-value } \\
\text { (diet) }\end{array}$} \\
\hline & CRN & SHGF & & \\
\hline GEI & $2,285.79$ & $2,427.17$ & 40.576 & 0.0014 \\
\hline $\mathrm{E}_{\text {feces }}$ & 725.04 & 831.25 & 33.459 & 0.047 \\
\hline DEI & $1,560.75$ & $1,595.93$ & 14.671 & 0.16 \\
\hline $\mathrm{E}_{\text {urine }}$ & 23.42 & 46.92 & 4.543 & 0.0049 \\
\hline $\mathrm{E}_{\text {methane }}$ & 101.38 & 96.44 & 1.414 & 0.068 \\
\hline MEI & $1,435.95$ & $1,452.56$ & 13.880 & 0.54 \\
\hline $\mathrm{HP}$ & 801.10 & 788.69 & 8.618 & 0.076 \\
\hline HPf & 16.03 & 14.30 & 0.279 & 0.0013 \\
\hline $\mathrm{RE}$ & 634.84 & 663.88 & 13.049 & 0.27 \\
\hline $\mathrm{E}_{\text {milk }}$ & 531.80 & 542.44 & 21.952 & 0.093 \\
\hline $\mathrm{TE}_{\text {body }}$ & 103.04 & 121.44 & 25.842 & 0.75 \\
\hline $\mathrm{k}_{\mathrm{l}-\mathrm{ARC}}$ & 0.62 & 0.64 & 0.008 & 0.22 \\
\hline $\mathrm{k}_{1}$ & 0.72 & 0.71 & 0.007 & 0.36 \\
\hline $\mathrm{k}_{\mathrm{g}}$ & 0.35 & 0.42 & 0.007 & 0.75 \\
\hline RQnp & 1.03 & 1.03 & 0.023 & 0.39 \\
\hline $\mathrm{NE}_{\mathrm{L}}, \mathrm{MJ} / \mathrm{kg}$ of $\mathrm{DM}$ & 7.44 & 7.59 & 0.095 & 0.56 \\
\hline
\end{tabular}

${ }^{1} \mathrm{GEI}=$ gross energy intake; $\mathrm{E}_{\text {feces }}=$ energy losses in feces; DEI $=$ di gestible energy intake; $\mathrm{E}_{\text {urine }}=$ energy losses in urine; $\mathrm{E}_{\text {methane }}=$ energy losses in methane; MEI = metabolizable energy intake; $\mathrm{HP}=$ heat production; $\mathrm{HPf}=$ heat production of fermentation $[\mathrm{HPf}=\mathrm{HP}-\mathrm{HP}$ of oxidation (Brouwer, 1958)]; RE = recovered energy ( $\mathrm{RE}=\mathrm{MEI}-$ $\mathrm{HP}) ; \mathrm{E}_{\text {milk }}=$ recovered energy in milk; $\mathrm{TE}_{\mathrm{body}}=$ recovered energy in tissue $\left(\mathrm{TE}_{\text {body }}=\mathrm{MEI}-\mathrm{HP}-\mathrm{E}_{\text {milk }}\right) ; \mathrm{k}_{\mathrm{l} \text {-ARC }}=$ efficiency of use of ME for milk production $\left[\mathrm{k}_{\mathrm{l}-\mathrm{ARC}}=\right.$ corrected milk energy $/\left(\mathrm{ME}-\mathrm{ME}_{\mathrm{M}}\right)$; $\operatorname{ARC}(1980)] ; \mathrm{k}_{1}=$ efficiency of ME for milk production $\left(\mathrm{k}_{1}=\mathrm{E}_{\text {milk }}\right)$ Prop $\times$ MEA, where Prop $=$ the fraction of MEA that is used for milk synthesis and MEA = MEI - 401); $k_{\mathrm{g}}=$ efficiency of ME for tissue retention $\left[\mathrm{k}_{\mathrm{g}}=\mathrm{TE}_{\mathrm{body}} /(1-\right.$ Prop $) \times \operatorname{MEA}$, where $(1-$ Prop $)=$ the fraction of MEA used for body tissue gain]; RQnp = nonprotein respiratory quotient $\left\{\mathrm{RQnp}=\left[\mathrm{CO}_{2}-(\mathrm{Nur} \times 6.25 \times 0.774)\right] /\left[\mathrm{O}_{2}-(\mathrm{Nur}\right.\right.$ $\times 6.25 \times 0.957)]$, where Nur $=$ urine-N $\} ; \mathrm{NE}_{\mathrm{L}}=\left(\mathrm{MEI} \times \mathrm{k}_{\mathrm{l}-\mathrm{ARC}}\right) / \mathrm{DMI}$. ${ }^{2} \mathrm{CRN}=$ corn diet; SHGF $=$ soy hulls and gluten feed diet. 
served $(P=0.076)$. This value is in the range of some values in the literature: Bava et al. (2001) found average values of 855 and $637 \mathrm{~kJ} / \mathrm{kg}$ of $\mathrm{BW}^{0.75}$ for Saanen goats at mid and late lactation, respectively and TovarLuna et al. (2010) with Alpine goats at mid lactation reported an average value of $737 \mathrm{~kJ} / \mathrm{kg}$ of $\mathrm{BW}^{0.75}$ when does consumed a $60 \%$ concentrate diet, and $634 \mathrm{~kJ} /$ $\mathrm{kg}$ of $\mathrm{BW}^{0.75}$ for does consuming $20 \%$ concentrate. No significant differences were observed for $\mathrm{E}_{\text {milk }}$ content $\left(537 \mathrm{~kJ} / \mathrm{kg}\right.$ of $\mathrm{BW}^{0.75}$, on average), whereas a tendency $(P=0.093)$ to a greater value for the SHGF diet than the CRN diet was found, probably linked to the significantly higher milk fat content value in the SHGF diet (Table 5). Therefore, the tissue energy recovered in the body did not differ between the CRN and SHGF diets (112 kJ $/ \mathrm{kg}$ of $\mathrm{BW}^{0.75}$, on average). The efficiency of use of ME for milk production, according to (ARC, 1980; $\mathrm{k}_{\mathrm{l}-\mathrm{ARC}}$ ) was calculated as $\mathrm{E}_{\text {milk }}$ output adjusted to zero energy balance divided by $\mathrm{ME}-\mathrm{ME}_{\mathrm{M}}$, and $\mathrm{ME}_{\mathrm{M}}$ was obtained from the estimation of Aguilera et al. (1990) for Granadina goats from both positive and negative energy retentions $\left(401 \mathrm{~kJ} / \mathrm{kg}\right.$ of $\left.\mathrm{BW}^{0.75}\right)$. No significant differences were observed between diets for $\mathrm{k}_{\mathrm{l}-\mathrm{ARC}}(0.63$, on average) and a similar value to that of Aguilera et al. (1990) was found with lactating Granadina goats $\left(\mathrm{k}_{1}=0.67\right)$. Bava et al. (2001) found values ranging from 0.60 to 0.73 for Saanen goats during lactation. Moreover, Tovar-Luna et al. (2010) with Alpine goats during lactation found values ranging from 0.66 to 0.78 . Those authors found variability when combining different stages of lactation with feed intake level, one of the reasons for differences in efficiencies being related to the complexity of biochemical transformation in tissues that are being synthesized or mobilized.

Dairy animals mobilize energy from body tissue to support energy requirements for milk production during early lactation and replenish mobilized tissue reserves during mid and late lactation for the subsequent lactation. It is generally accepted that the utilization of ME for milk secretion $\left(\mathrm{k}_{\mathrm{l}}\right)$ in lactating cows in positive energy balance is a more efficient process than that

Table 5. Daily milk production (g/d) and composition (\%) of Murciano-Granadina goats $(\mathrm{n}=20)$ during mid lactation according to the type of diet

\begin{tabular}{lrrrl}
\hline & \multicolumn{2}{c}{ Diet $^{1}$} & & \\
\cline { 2 - 3 } Item & CRN & SHGF & SEM & $\begin{array}{c}P \text {-value } \\
\text { (diet) }\end{array}$ \\
\hline Milk yield, kg/d & 2.24 & 2.11 & 0.079 & 0.36 \\
Milk DM & 15.01 & 16.60 & 0.306 & 0.0022 \\
Milk fat & 5.44 & 7.02 & 0.558 & 0.029 \\
Milk protein & 4.04 & 4.07 & 0.091 & 0.53 \\
Milk lactose & 4.74 & 4.71 & 0.062 & 0.83 \\
\hline
\end{tabular}

${ }^{1} \mathrm{CRN}=$ corn diet; SHGF $=$ soy hulls and gluten feed diet. for tissue retention $\left(\mathrm{k}_{\mathrm{g}}\right)$ by nonlactating cows (ARC, 1980). However, doubt exists concerning the efficiency with which energy is retained in tissue when it occurs simultaneously with lactation. In this study, we found no significant differences between diets and greater efficiency of ME use for lactation than retention. In our attempt to estimate the efficiency of $\mathrm{ME}$ for milk and body retention, we found an average value of 0.72 for $\mathrm{k}_{1}$ and 0.39 for $\mathrm{k}_{\mathrm{g}}$. Yan et al. (1997) indicated that a decrease in energy of $1 \mathrm{MJ} / \mathrm{d}$ for milk synthesis was associated with an increase in tissue energy retention of 0.96 . Those authors recommend for practical purposes the same value for $k_{1}$ and $k_{g}$. Moe et al. (1970) found that the efficiency of energy deposition in lactating cows was as high as the efficiency of use for milk production. This is the view of the Ministry of Agriculture, Fisheries and Food (MAFF, 1984), which used the value 0.62 for both ME conversion efficiencies. As mentioned above, the ARC (1980) predicts $\mathrm{k}_{\mathrm{g}}$ for energy storage during lactation as $0.95 \mathrm{k}_{1}$. The Commonwealth Scientific and Industrial Research Organisation (CSIRO, 2007) reported a general value of 0.60 for conversion of ME to gain; the same value for $k_{1}$ and $k_{g}$. The evidence in the literature on comparative efficiencies of ME utilization for milk secretion and for concomitant tissue retention is conflicting. Higher $\mathrm{k}_{1}$ than $\mathrm{k}_{\mathrm{g}}$ may partially relate to the relatively lower mass of tissue contributing to RE that must be maintained by lactating than growing/finishing animals, thereby resulting in a relatively lower energy turnover:synthesis ratio for lactation (NRC, 2007). Furthermore, the contribution of lactose to energy in milk and relatively less energy in protein in milk than in accreted tissue by growing animals in many instances may be involved in high $\mathrm{k}_{\mathrm{l}}$ relative to $\mathrm{k}_{\mathrm{g}}$.

The energy content of the diets was calculated $\left(\mathrm{NE}_{\mathrm{L}}\right.$, $\mathrm{MJ} / \mathrm{kg}$ of $\mathrm{DM}$ ) as $\mathrm{k}_{\mathrm{l}-\mathrm{ARC}}$ (adjusted to zero energy balance) multiplied by ME. No significant differences were found when substituting corn with soy hulls and gluten feed and the feeding level was 3.6 times maintenance [assuming $401 \mathrm{~kJ}$ of $\mathrm{ME}_{\mathrm{M}} / \mathrm{kg}$ of $\mathrm{BW}^{0.75}$ according to Aguilera et al. (1990)]. The average value obtained was $7.52 \mathrm{MJ} / \mathrm{kg}$ of DM. Bava et al. (2001) with goats at mid lactation found values of 8.53 and $7.70 \mathrm{MJ} / \mathrm{kg}$ of $\mathrm{DM}$ for silage basis diet and nonforage diet, respectively.

\section{Oxidation of Nutrients}

The $\mathrm{CO}_{2}$ production is derived from nutrient oxidation and rumen fermentation. So, separation between these 2 components is necessary to calculate the substrate oxidation in ruminants and determine the proportion of substrate oxidation supporting the total HP associated with oxidative processes. The production 
Table 6. Daily oxidation $\left(\mathrm{kJ} / \mathrm{kg}\right.$ of $\left.\mathrm{BW}^{0.75}\right)$ of protein (OXP), carbohydrate (OXCHO), and fat (OXF) and their contribution to the heat production (HP) from oxidation substrates ( $\mathrm{HPx}$ ) of MurcianoGranadina goats $(\mathrm{n}=20)$ during mid lactation according to the type of diet

\begin{tabular}{lrrrl}
\hline & \multicolumn{2}{c}{ Diet $^{1}$} & & \\
\cline { 2 - 3 } Item & CRN & SHGF & SEM & $\begin{array}{c}P \text {-value } \\
\text { (diet) }\end{array}$ \\
\hline HPx $^{2}$ & 785.07 & 774.39 & 8.474 & 0.11 \\
OXP & 104.26 & 137.70 & 7.407 & 0.0005 \\
OXCHO & 447.68 & 412.03 & 51.049 & 0.27 \\
OXF & 232.88 & 224.31 & 49.842 & 0.56 \\
OXP/HPx & 13.31 & 17.82 & 0.976 & 0.0011 \\
OXCHO/HPx & 56.94 & 53.49 & 6.593 & 0.28 \\
OXF/HPx & 29.71 & 28.65 & 6.587 & 0.50 \\
\hline
\end{tabular}

${ }^{1} \mathrm{CRN}=$ corn diet; SHGF $=$ soy hulls and gluten feed diet.

${ }^{2}$ Heat production from oxidation of nutrients.

of VFA from carbohydrate fermentation is followed by $\mathrm{CO}_{2}$ and $\mathrm{CH}_{4}$ production. From the molar proportion of SCFA (Table 3) it is possible to obtain an estimation of the $\mathrm{CO}_{2}: \mathrm{CH}_{4}$ ratio, following the theoretical rumen fermentation balance proposed by Wolin (1960): 1.7 and 1.6 for the CRN and SHGF diets, respectively. The proportional contribution to HPx due to oxidation of nutrients with the 2 diets is shown in Table 6 .

Oxidation of nutrients was not statistically different between the 2 diets, with the exception of protein. First, no significant differences were observed for $\mathrm{HPx}$ $\left(780 \mathrm{~kJ} / \mathrm{kg}\right.$ of $\mathrm{BW}^{0.75}$, on average). The OXP was significantly $(P<0.05)$ greater for the SHGF than the CRN diet (138 vs. $104 \mathrm{~kJ} / \mathrm{kg}$ of $\mathrm{BW}^{0.75}$, on average). The heat from OXP contributed approximately 13 and $18 \%$ of HPx in the CRN and SHGF diets, respectively $(P<0.05)$. As previously mentioned, the SHGF diet decreased the utilization of ammonia $\mathrm{N}$ (Table 3 ). This probably accounts for the greater values of OXP observed for the SHGF diet; an asynchrony seems to exist between rumen carbohydrate degradability and RDP to maximize microbial protein synthesis to support milk production, as reported by Casper et al. (1999).

Due to the positive energy balance, without significant differences between diets during mid lactation in this trial, the OXCHO $\left(430 \mathrm{~kJ} / \mathrm{kg}\right.$ of $\mathrm{BW}^{0.75}$, on average) was higher than OXF $\left(229 \mathrm{~kJ} / \mathrm{kg}\right.$ of $\mathrm{BW}^{0.75}$, on average). Taking average figures, most of the $\mathrm{HPx}$ derived from OXCHO (55\%, on average), followed by OXF ( $29 \%$, on average). It seems that the greater OXCHO and lower OXF found in the 2 diets would be, in part, responsible for the positive recovered tissue energy in the body $\left(112 \mathrm{~kJ} / \mathrm{kg}\right.$ of $\mathrm{BW}^{0.75}$, on average; Table 4). When carbohydrate-rich diets were offered, van den Borne et al. (2007) reported that animals tended to have increased rates of de novo FA synthesis from glucose with low feed frequency and less fat mobi- lization. In our study, fibrous by-products had similar behavior to the diet rich in corn (high-starch level). We must bear in mind that the gas exchange method does not discriminate between oxidation of exogenous and endogenous glucose, so this more closely represents net catabolism of glucose. Few studies relating to oxidation of nutrients are available for ruminants and especially for small ruminants. Chwalibog et al. (1997) in calves with positive recovered energy as fat pointed out that part of OXF should originate from ingested carbohydrate, mainly fiber. Fernández et al. (2012b) found in Manchega sheep that in fasting conditions most of the HPx was due to OXF (93\%), although OXCHO increased with a feeding level up to a stable value of $51 \%$.

\section{Milk Production}

As the diets were balanced in nutrient requirements for lactating goats and both were mixed diets, goats had similar and nonsignificant milk yield, despite the different amount of starch (Table 5). Average milk yield was $2.18 \mathrm{~kg} / \mathrm{d}$, and this is consistent with the results obtained by Sanz Sampelayo et al. (1998) in Granadina goats fed long or pelleted alfalfa hay and with those of Bava et al. (2001) with Saanen goats or Tovar-Luna et al. (2010) with Alpine goats.

Milk fat content was statistically different between the 2 diets (7.02 and $5.44 \%$ for the SHGF and CRN diets, respectively) and consequently milk DM content (16.60 vs. 15.01\%). This is because the SHGF diet had higher fiber content than the CRN diet (48 vs. $35 \%$ NDF, on average), greater $(P<0.05)$ NDF digestibility than the CRN diet (50 vs. $37 \%$, respectively), and higher $(P<0.05)$ acetic acid production $(64$ vs. 60 mol/100 mol, respectively). van Knegsel et al. (2007) showed that the milk fat level was usually elevated after feeding extra lipogenic nutrients; these originated from fiber, or from dietary fat or derived from body reserves. Those authors replaced $27 \%$ of corn with $29 \%$ of beet pulp in dairy cows. Mahjoubi et al. (2009), adding beet pulp to dairy cows at late lactation in substitution of barley grain, increased milk energy output mainly because of increased milk fat output. Milk protein and lactose contents were not statistically different between treatments (4.06 and $4.73 \%$, respectively, on average).

\section{CONCLUSIONS}

This paper provides data for energy partitioning and substrate oxidation of nutrients in Murciano-Granadina goats during mid lactation fed a diet with $37 \%$ corn and substituted by the same amount of fibrous by-product (soy hulls and gluten feed blend). The MEI was not different between the CRN and SHGF treat- 
ments, with an average value of $1,444 \mathrm{~kJ} / \mathrm{kg}$ of $\mathrm{BW}^{0.75}$. The efficiency of use of ME for milk production ( $\mathrm{k}_{\mathrm{l} \text { ARC }}$ ) adjusted to zero energy balance was 0.63 . The nutritive value of the diets was $7.52 \mathrm{MJ}$ of $\mathrm{NE}_{\mathrm{L}} / \mathrm{kg}$ of $\mathrm{DM}$, on average. No significant differences between diets were found for HPx derived from OXF (29\%, on average) and from $\mathrm{OXCHO}$ (55\%, on average). Greater and significant values were found for the SHGF diet for ammonia $\mathrm{N}$, urine energy losses, OXP, and significantly lower for HP of fermentation, indicating a decrease in rumen fermentation for this diet. Probably due to an excess of $\mathrm{CP}$ in the diet and lack of synchronization of the NFC and RDP. Milk production and DMI were similar for goats fed the diet based on corn than those for goats fed the diet based on fibrous by-products. Milk fat and acetic acid were greater for goats fed soy hulls and corn gluten feed blend as a replacement for corn grain. This fibrous by-product was utilized by lactating goats without detrimental effect on energy metabolism and resulted in similar performance to a traditional diet. The economic advantages and sustainability of this choice should be evaluated.

\section{ACKNOWLEDGMENTS}

This study was supported by an Instituto Nacional de Investigación y Tecnologia Agraria (INIA, Madrid, Spain) project (ref. RTA2011-00107-C02-02).

\section{REFERENCES}

Aguilera, J. F., and C. Prieto. 1986. Description and function of an open-circuit respiration plant for pigs and small ruminants and the techniques used to measure energy metabolism. Arch. Tierernähr. 36:1009-1018

Aguilera, J. F., C. Prieto, and J. Fonollá. 1990. Protein and energy metabolism of lactating Granadina goats. Br. J. Nutr. 63:165-175.

AOAC International. 2000. Official Methods of Analysis. 17th ed. AOAC International, Arlington, VA.

ARC (Agricultural Research Council). 1980. The Nutrient Requirements of Ruminant Livestock. Technical Review. CAB, Farnham Royal, Wallingford, UK.

Batey, I. L. 1982. Starch analysis using thermostable alpha-amylases. Starch/Stärke 34:125-128.

Bava, L., L. Rapetti, G. M. Crovetto, A. Tamburini, A. Sandrucci, G. Galassi, and G. Succi. 2001. Effect of a nonforage diet on milk production, energy, and nitrogen metabolism in dairy goats throughout lactation. J. Dairy Sci. 84:2450-2459.

Brockway, J. M., A. W. Boyne, and J. G. Gordon. 1971. Simultaneous calibration of gas analyzers and meters. J. Appl. Physiol. 31:296-297.

Brouwer, E. 1958. On simple formulae for calculating the heat expenditure and the quantities of carbohydrate and fat metabolized in ruminants, from data on gaseous exchange and urine N. Pages 182-194 in Proc. 1st Symp. Energy Metab. EAAP Publ. 8. Academic Press, London, UK.

Brouwer, E. 1965. Report of sub-committee on constants and factors. Pages 441-443 in Proc. 3rd Symp. Energy Metab. EAAP Publ. 11. K. L. Blaxter, ed. Academic Press, London, UK.
Casper, D. P., H. A. Maiga, M. J. Brouk, and D. J. Schingoethe. 1999. Synchronization of carbohydrate and protein sources on fermentation and passage rates in dairy cows. J. Dairy Sci. 82:1779-1790.

Chwalibog, A., A.-H. Tauson, and G. Thorbek. 1997. Quantitative oxidation of nutrients in growing calves. Z. Ernährungswiss. $36: 313-316$.

CSIRO (Commonwealth Scientific and Industrial Research Organisation). 2007. Nutrient Requirements of Domesticated Ruminants. CSIRO, Collingwood, Australia.

Drewnoski, M. E., M. H. Poore, and G. A. Benson. 2011. Effect of frequency of supplementation of a soy hulls and corn gluten feed blend on hay intake and performance of growing steers. Anim. Feed Sci. Technol. 164:38-44.

European Council. 2003. Protection of animals used for experimental purposes. Council Directive 86/609/EEC of 24 November 1986, amended 16.9.2003. European Council, Brussels, Belgium.

Fahey, G. C., and L. L. Berger. 1988. Carbohydrate nutrition of ruminants. Pages 269-297 in The Ruminant Animal. Digestive Nutrition and Physiology. D. C. Church, ed. Prentice-Hall, Englewood Cliffs, NJ.

FEDNA (Fundación Española para el Desarrollo de la Nutrición Animal). 2009. Nutritional Requirements for Dairy Ruminants. FEDNA, Madrid, Spain.

Fernández, C., M. C. López, and M. Lachica. 2012a. Description and function of a mobile open-circuit respirometry system to measure gas exchange in small ruminants. Anim. Feed Sci. Technol. $172: 242-246$.

Fernández, C., M. C. López, and M. Lachica. 2012b. Heat production determined by the RQ and CN methods, fasting heat production and effect of the energy intake on substrates oxidation of indigenous Manchega sheep. Anim. Feed Sci. Technol. 178:115-119.

Firkins, J. L. 1997. Effect of feeding nonforage fiber sources on site of fiber digestion. J. Dairy Sci. 80:1426-1437.

Hoover, W. H., and S. R. Stokes. 1991. Balancing carbohydrates and proteins for optimum rumen microbial yield. J. Dairy Sci. 74:3630-3644.

Huntington, G. B. 1997. Starch utilization by ruminants: From basics to the bunk. J. Anim. Sci. 75:852-867.

Interal (Interprofesional Española de la Alimentación Animal). 2008. Estudio de Posicionamiento Estratégico para el Sector de la Alimentación Animal en el Escenario Actual. Editorial Agricola Española SA, Madrid, Spain.

Islam, M., H. Abe, Y. Hayashi, and F. Terada. 2000. Effects of feeding Italian ryegrass with corn on rumen environment, nutrient digestibility, methane emission, and energy and nitrogen utilization at two intake levels by goats. Small Rumin. Res. 38:165-174.

Jouany, J. P. 1982. Volatile fatty acid and alcohol determination in digestive contents, silage juices, bacterial cultures and anaerobic fermentor contents. Sci. Aliments 2:131-144.

Lachica, M., and J. F. Aguilera. 2003. Estimation of energy needs in the free-ranging goat with particular reference to the assessment of its energy expenditure by the ${ }^{13} \mathrm{C}$-bicarbonate method. Small Rumin. Res. 49:303-318.

Ludden, P. A., M. J. Cecava, and K. S. Hendrix. 1995. The value of soybean hulls as a replacement for corn in beef cattle diets formulated with or without added fat. J. Anim. Sci. 73:2706-2711.

MAAMA (Ministerio de Agricultura, Alimentación y Medio Ambiente). 2012. Estadísticas lácteas, resultados 2001 a 2010. Accessed Oct. 10, 2012. http://www.magrama.gob.es/es/estadistica/temas/ estadisticas-agrarias/ganaderia/estadistica-industrias-lacteas/ estadistica-lactea-anual/.

MAFF (Ministry of Agriculture, Fisheries and Food). 1984. Energy Allowances and Feeding Systems for Ruminants. ADAS Reference book 433. Her Majesty's Stationery Office (HMSO), London, UK.

Mahjoubi, E., H. Amanlou, D. Zahmatkesh, M. Ghelich Khan, and N. Aghaziarati. 2009. Use of beet pulp as a replacement for barley grain to manage body condition score in over-conditioned late lactation cows. Anim. Feed Sci. Technol. 153:60-67.

McLean, J. A., and G. Tobin. 1987. Animal and Human Calorimetry. Cambridge University Press, Cambridge, UK. 
Moe, P. W., H. F. Tyrrell, and W. P. Flatt. 1970. Partial efficiency of energy use for maintenance, lactation, body gain, and gestation in the dairy cow. Page 65 in Proc. 4th Symp. Energy Metab. EAAP Publ. 13. Academic Press, London, UK.

NRC. 2001. Nutrient Requirements of Dairy Cattle. 7th rev. ed. Natl. Acad. Press, Washington, DC.

NRC. 2007. Nutrient Requirements of Small Ruminants: Sheep, Goats, Cervids, and New World Camelids. Natl. Acad. Press, Washington, DC.

Santini, F. J., C. D. Lu, M. J. Potchoiba, J. M. Fernandez, and S. W. Coleman. 1992. Dietary fiber and milk yield, mastication, digestion and rate of passage in goats fed alfalfa hay. J. Dairy Sci. 75:209-219.

Sanz Sampelayo, M. R., L. Perez, J. Boza, and L. Amigo. 1998. Forage of different physical forms in the diets of lactating Granadina goats: Nutrient digestibility and milk production and composition. J. Dairy Sci. 81:492-498.

SAS Institute. 2001. User's Guide. Version 8.02, SAS Institute Inc., Cary, NC.

Tovar-Luna, I., R. Puchala, T. Sahlu, H. C. Freetly, and A. L. Goetsch. 2010. Effects of stage of lactation and dietary concentrate level on energy utilization by Alpine dairy goats. J. Dairy Sci. 93:4818 4828 .

van den Borne, J. J. G. C, G. E. Lobley, M. W. A. Verstegen, J.-M. Muijlaert, S. J. J. Alferink, and W. J. J. Gerrits. 2007. Body fat deposition does not originate from carbohydrate in milk-fed calves. J. Nutr. 137:2234-2241.

van Knegsel, A. T. M., H. van den Brand, J. Dijkstra, W. M. van Straalen, M. J. W. Heetkamp, S. Tamminga, and B. Kemp. 2007. Dietary energy source in dairy cows in early lactation: Energy partitioning and milk composition. J. Dairy Sci. 90:1467-1476.

Van Soest, P. J., J. B. Robertson, and B. A. Lewis. 1991. Methods for dairy fiber, neutral detergent, and nonstarch polysaccharides in relation to animal nutrition. J. Dairy Sci. 74:3583-3597.

Waldo, D. R. 1973. Extent and partition of cereal grain starch digestion in ruminants. J. Anim. Sci. 37:1062-1074.

Wolin, M. J. 1960. A theoretical rumen fermentation balance. J. Dairy Sci. 43:1452-1459

Yan, T., F. J. Gordon, C. P. Ferris, R. E. Agnew, M. G. Porter, and D. C. Patterson. 1997. The fasting heat production and effect of lactation on energy utilization by dairy cows offered forage-based diets. Livest. Prod. Sci. 52:177-186. 